\title{
THE IMPACT OF PROJECT RISK AUDITS ON CONSTRUCTION PROJECT SUCCESS
}

\author{
UDC: 624.05:005.8 \\ 624.05:657.6 \\ Original Scientific Paper \\ Kennedy Christopher OBONDI ${ }^{1}$ \\ ${ }^{1}$ School of Business, Northcentral University, 11355 N. Torrey Pines Road, La Jolla, CA 92037 USA \\ E-mail: kobondi@yahoo.com
}

Paper received: 29.10.2020.; Paper accepted: 09.12.2020.

\begin{abstract}
Risk audit is often poorly implemented in construction projects because of the absence of constant auditing of risks by construction project managers. Construction companies are experiencing large financial deficits because of managers failing to audit and monitor project risks. The purpose of this study was to examine whether the utilization of risk audit correlates with project success in construction projects. An electronic survey instrument was used to collect data from a sample of 50 construction project managers in the Dallas-Fort Worth area of Texas in the United States. Spearman's rho correlational analysis and simple logistic regressions were used to examine the relationship between risk audit and project success. The results of this study indicated that there is a positive and significant association between risk audit and project success in terms of schedule performance, cost performance, customer satisfaction, and business success. One of the recommendations presented in this study was to expand the study to developing countries to see whether the findings from the study remain the same. The study concluded that construction organizations should regularly consider the importance and usage of risk audit techniques to improve the success rate of a project.
\end{abstract}

Keywords: Construction project management; Project success; Auditing; Project risk audits; Project auditing.

\section{INTRODUCTION}

Risk audit is the examination of the effectiveness of risk responses and risk management processes in dealing with risks and their root causes (Project Management Institute, 2017). Risk audit is often poorly implemented in construction projects because of the absence of constant auditing of risks by construction project managers. Construction companies often experience significant losses because project managers do not continuously and adequately audit risks in construction projects that they oversee. Construction project managers often use improper risk management methods when managing and controlling risks. Frequently, rather than following proper risk management processes, project managers utilize personal instincts for both managing and mitigating risks (Qazi, Quigley, Dickson, \& Kirytopoulos, 2016). To navigate in an increasingly volatile project environment, it is imperative for a project manager to regularly audit and actively manage the project's collective risks, as well as those related to its business partners (e.g., suppliers, clients, banks, insurance companies, etc.) (Lu, 2004).

If project risks are inadequately audited and controlled in a construction project, a cascade of problems can ensue, including accidents, cost overruns, delays in schedules, design errors, equipment failure, labor strikes, low customer satisfaction, poor quality work, structural failure, and, ultimately, even project failure (Khan \& Gul, 2017). The failure of a project can be detrimental to bottom-line performance, reputation, share price, stakeholder confidence, and the realization of the strategic objectives of an organization (Chapman, 2019). In construction projects, risks must be audited continuously to deliver successful project outcomes. 
According to Shilts (2017), organizations are investing time and money in continuous auditing to assess and control risks in a project. Continuous auditing concentrates on testing for the pervasiveness of risk and the effectiveness of control and provides a more in-depth understanding of risks and controls from periodic project reviews. For example, continuous auditing includes performing trend analysis on a project's expense accounts to identify variances that management must act on in the event of a potential risk facing a project. Continuous monitoring and continuous auditing can improve the risk management and control activities of virtually any project (Hardy, \& Laslett, 2015).

Although continuous auditing involves high implementation costs, the application of continuous auditing in construction projects improves accountability and risk control management (Eulerich, \& Kalinichenko, 2018; Lombardi, Vasarhelyi, \& Verver, 2014). It increases the protection of project cash flow from being manipulated, improves fraud deterrence due to closer detection of fraud, strengthens vendor relations creating more effective procedures, stabilizes risk controls, and minimizes inherent risks. Additionally, project risk audits help to improve the performance of the project, enhance customer and stakeholder satisfaction, save costs, control scope to avoid scope creep, provide early problem diagnostics, clarify performance, cost, and schedule relationships. Risk audits identify future opportunities for improvement, evaluate the performance of the project team, inform the client of project status/prospects, and reconfirm the feasibility of commitment to the project.

\section{Statement of the Problem}

The problem addressed in this study is that construction companies are experiencing large financial deficits because of the absence of constant risk auditing by construction project managers in construction projects they oversee. These financial deficits can sometimes amount to approximately $85 \%$ of the total cost of a project (Senesi, Javernick-Will, \& Molenaar, 2015). The problem of inadequate project risk audits exists because project teams see the audit operation as a ploy to expose their inadequacies and shortcomings. Such perceptions can prevent the risk audit team from accessing the information needed to complete their work. While the absence of risk audits in construction projects is known to cause project failure, what remains unknown is how the implementation of the risk audits technique impact the level of project success in construction projects in the United States.

\section{Purpose of the Study}

The purpose of this study was to examine whether the utilization of the risk audits technique correlates with project success in construction projects in the United States. Specifically, the main objectives of this study were to:

- Examine the relationship between risk audits and project success in construction projects.

- Examine the predictive magnitude of the relationship between risk audits and project success in construction projects.

\section{Research Questions and Hypotheses}

This research aimed to address the following research questions (RQs):

RQ1: To what extent is the utilization of risk audits related to project success in construction projects?

RQ2: To what extent do risk audits predict project success?

The proposed hypotheses for this study are:

H01: There is no positive relationship between risk audits and project success in construction projects.

Ha1: There is a positive relationship between risk audits and project success in construction projects.

H02: There is no predictive effect of risk audits on project success in construction projects.

Ha2: There is a predictive effect of risk audits on project success in construction projects.

\section{Significance of the Study}

This study will serve as a source of knowledge that practitioners may utilize either to manage or respond to risks in their area of practice. This study will provide project management practitioners with a more profound and detailed understanding of the benefits and relationships that exist between risk audits and project performance. The findings from this study will aid organizations in solving project risk management issues to ensure the successful completion of their projects. The results from this study will help close the gap in this underexplored 
project risk management practice. If a connection exists between project success and the use of risk audits, then a genuine reason could exist for the increased use of risk audit technique as a guideline for improving and enhancing the implementation of risk management in the construction industry.

\section{METHOD}

This study used a quantitative non-experimental correlational design to address the research problem. Quantitative research techniques are used to test hypotheses, evaluate findings, generalize findings to a population, and encourage replication of the findings (Park, \& Park, 2016). Quantitative methods are efficient in procuring large amounts of data within a given time (McCusker, \& Gunaydin, 2015). Using qualitative methodologies, researchers explore the meanings of a phenomenon as understood by research participants and limit the generalization of the findings to the particular group under analysis. Qualitative methods do not test hypotheses and generalize research findings (McCusker, \& Gunaydin, 2015). Since this study is focused on testing hypotheses and generalizing the results, qualitative methods were not suitable for this study. Although mixed methods could have been used in this study, using mixed methods can be expensive and time-consuming, especially when gathering qualitative and quantitative data simultaneously.

This study used a non-experimental design. Unlike experimental designs, non-experimental designs do not directly manipulate variables as in a real experiment (Curtis, Comiskey, \& Dempsey, 2016; Podsakoff, \& Podsakoff, 2019). Non-experimental designs use inferential statistics to establish associations. Furthermore, experimental research may be too costly and raise ethical concerns, especially when a researcher manipulates and controls variables (Podsakoff, \& Podsakoff, 2019).

A correlational design was the preferred methodology for this study. Correlational studies explore and examine relationships between and among variables (Curtis, Comiskey, \& Dempsey, 2016). Correlational studies allow a researcher to better understand the relationship between variables. For example, this study explored and observed the relationship between risk audits and project success in construction projects. In the descriptive research design, this would be impossible as this design does not allow for the identification of relationships between variables.
Therefore, considering the nature of the research question, time, cost, and the generalization of research findings, this current study used a quantitative non-experimental correlational design to answer the research problem and its research questions.

The research questions for this study were structured to examine if a relationship existed between the utilization of risk audits technique and project success in construction projects. In this study, risk audits acted as the independent variable while project success was the dependent variable. The research tested the hypotheses to determine if a statistically significant relationship existed between the independent variable and the dependent variable. Figure 1 presents the research model for this study.

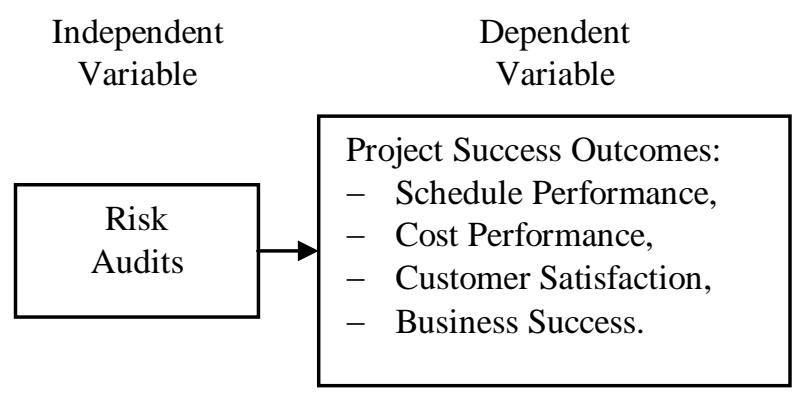

Figure 1: Research Model

The variables measured in this study were risk audits as an independent variable and project success as a dependent variable. In this study, the risk audits independent variable was measured using frequencies (in terms of percentages) of risk audits method usage to understand better if project managers account for and utilize risk audit planning in construction projects. The project success dependent variable was measured based on the project success dimensions of schedule, cost, customer satisfaction, and business success (Shenhar, Levy, \& Dvir, 1997; Todorovic, Petrovic, Mihic, Obradovic, \& Bushuyev, 2015). Data analysis was conducted via SPSS software using Spearman's rho correlations analysis and simple logistic regressions to predict the relationships between the independent and dependent variables.

The construction industry is subjected to a higher level of risks than that of other industries due to the dynamic and complex nature of construction activities. Internal and external factors such as project complexity, scope changes, schedule and 
budget constraints, complex procedures, technical difficulties, and hostile environments are some of the main causes of risk in construction projects (Alashwal, \& Al-Sabahi, 2018). The problem addressed in this study was that construction companies are experiencing large financial deficits because of a lack of constant risk auditing by construction project managers in construction projects they supervise. Sometimes these financial deficits can amount to approximately $85 \%$ of the total cost of a project (Senesi, Javernick-Will, \& Molenaar, 2015). The purpose of this quantitative non-experimental correlational study was to examine whether the utilization of risk audits is correlated with project success in construction projects in the United States.

\section{Population and Sample}

This research study took place in the Dallas-Fort Worth area of Texas. The study included construction project managers who met the following criteria: Each construction project manager (a) must have been currently employed as a project manager and had a minimum of three years of experience managing construction projects, (b) must have managed risk on a completed construction project, (c) must have possessed an academic or professional qualification or a bachelor's degree or higher, and (d) must have been employed in a construction company in the Dallas-Fort Worth area.

Given the study's problem, purpose, and research question, the construction project managers were selected as a unit of analysis given their knowledge of project management. To recruit participants, the researcher used Qualtrics, a research website company that allows participants to confidentially complete a survey during the data collection process. Construction project managers were recruited through the Qualtrics research company website. Qualtrics provided the sample frame, and construction project managers who are members of Qualtrics' expert panels that fit the sample frame were selected and invited to participate in the study.

A probability random sampling design whereby each population element has an equal chance of selection was used. According to Polit and Beck (2010), random sampling enables generalization in evidence-based practice and provides relevance of the research for people outside the sample under study. A total of 63 construction project managers participated in this study by responding to an online survey using Qualtrics as an interface platform for the research. Of the 63 responses received, 50 responses were complete. Therefore, the sample size for this study was 50 respondents.

For this study, a reliable and valid survey instrument that could be used to examine whether the utilization of risk audits was related to project success in construction projects could not be found. As a result, a new survey instrument was developed by the researcher for use in the current quantitative correlational study, to serve the purpose and solve the research problem. The creation of the survey instrument for the current study relating to project risk audits and project success entailed several theoretical constructs, as identified in the earlier studies of Thaheem and De Marco (2013) and Jayasudha, Vidivelli, and Surjith (2014). The emphasis put on the content was based on studies by D'souza (2012), El-Sayegh (2014), and Ryor (2013) relating to project risk management practices. The survey also included theoretical constructs relating to project success, as outlined in the studies of Shenhar and Dvir (2007), Besteiro, Pinto, and Novaski (2015), Williams (2016), and Sohu et al. (2018).

Since a new survey instrument was developed for this study, a field test was required to establish the content and face validity of the survey instrument. Before collecting data, a panel of three experts reviewed the survey instrument. The experts were two professors in the project management field with knowledge of project management and one research consultant with knowledge of the academic research process. These professionals were selected from outside the population of the study to avoid conflict of interest and bias in research. These experts were asked to review the survey questions to ensure the questions were accurate, appropriate, and in a logical sequence. The experts' recommendations regarding the survey questions were used to improve the survey instrument.

The data collection for the full study was conducted from $1 / 3 / 2020$ to $1 / 25 / 2020$. The developed survey instrument collected data regarding the demographics of the respondents, their responses regarding the use of the risk audit method, and levels of project success within the construction industry. The survey was divided into three sections. 
Section one of the survey instrument collected responses regarding the demographics of participants. The demographic information that were collected included age, years of experience as a project manager, level of education, job title, and professional qualifications or certifications. Besides ensuring that the participants of the study met the criteria required to participate in the study, their demographic information provided an overview of the sample for generalization purposes (Ott, \& Longnecker, 2015).

Section two of the instrument collected participant responses regarding the usage of risk audits. In this section, an assessment of the risk audits method that research participants used was carried out covering frequencies (in terms of percentages) of usage of risk audits technique to understand better if project managers account for and utilize risk audit planning in construction projects.

Section three of the survey concentrated on collecting participant responses regarding project success outcomes (in terms of schedule performance, cost performance, customer satisfaction, and business success) received from the utilization of risk audits technique. A 5-point Likert scale with potential responses ranging from $1=$ Strongly disagree to $5=$ Strongly agree was used, and respondents were required to respond accordingly. A Likert scale is a psychometric measurement scale widely used in survey research in which respondents specify their level of agreement to a statement (Jayasudha, Vidivelli, \& Surjith, 2014).

Research participants were construction project managers from the Dallas-Fort Worth area of Texas, in the United States. Research participants were recruited using the research website Qualtrics.com. Qualtrics provided the sample frame, and construction project managers who are members of Qualtrics' expert panels that fit the sample frame were selected and invited to participate in the study. An online survey tool hosted by Qualtrics was used for data administration and collection. Qualtrics sent recruitment emails to the research participants which included an informed consent and a link to the survey. The respondents were asked to read an informed consent letter that communicated the objectives and scope of the research and participants' rights. Participants were asked to click the "I Agree" button to signify their willingness to participate. Once the research participant agreed to continue with the study, the survey was activated and administered online through a 24-hour accessible Qualtrics website. The survey took 15 to 20 minutes to complete.

The survey method was used in this study to seek explanations and predictions from research participants with the intent to establish, confirm, or validate relationships, and to generalize the contributions of existing theories (Leedy, \& Ormrod, 2013). Since risks are prevalent in construction projects and affect construction project performance, this survey was conducted to examine whether the utilization of risk audits is related to project success in the construction industry. After data collection, the researcher downloaded the data from the Qualtrics website that was compatible with the SPSS software. This process allowed the researcher to migrate the data into SPSS software to be analyzed.

\section{RESULTS}

After the data were collected and prepared for data analysis, SPSS was used to analyze the data. Before conducting statistical analysis, a review of the data set was necessary to validate the assumptions of normality and linearity of the data distributions for the correlated variables (i.e., risk audits, schedule performance, cost performance, customer satisfaction, and business success). There are many methods available to test for normality. Skewness and kurtosis statistics were the methods that were selected in this study. Both kurtosis and skewness have ranges for normal data. Kurtosis represents the extent to which observations collect around a central mean. Kurtosis values should range from +3 to -3 to be considered normal (Coakes, \& Steed, 2009). Skewness measures the asymmetry of the distribution of value around the mean. Skewness should range from +1 to -1 to be considered normal (Hair, Money, Samouel, \& Page, 2006). However, Kline (2005) proposed that if a skewness value was located between +3 and -3 , then the value would be acceptable. In this current study, if either statistic was above an absolute value of 2.0, then the assumption of normality was violated. Table 1 shows the results of the skewness and kurtosis test for normality. 
Table 1: Skewness and Kurtosis Test for Normality

\begin{tabular}{|l|c|c|}
\hline Variable & Skewness & Kurtosis \\
\hline Risk Audits & -1.45 & 4.25 \\
\hline Schedule Performance & -0.82 & 0.13 \\
\hline Cost Performance & -0.37 & -0.44 \\
\hline Customer Satisfaction & -0.55 & -0.51 \\
\hline Business Success & -0.77 & 0.90 \\
\hline
\end{tabular}

The kurtosis statistics in Table 1 indicated that the statistical assumption of normality was violated for risk audits, the independent variable. However, for each of the four components of project success, the dependent variable (schedule performance, cost performance, customer satisfaction, and business success) assumption of normality was met. Since the normal distribution was violated, a nonparametric Spearman's rho correlational analysis was used in this study rather than the traditional Pearson's correlation. Spearman's rho correlational analysis does not assume normal data distribution. Since this study was quantitative, nonexperimental correlational, the researcher investigated whether relationships existed between independent and dependent variables using Spearman's rho correlation analysis. This type of analysis allows for the testing of relationships between two variables and indicates the significant relationships between the dependent and independent variables (Hoffman, \& Shafer, 2015). Spearman's rho correlational analysis allowed for the testing of relationships between the risk audits independent variable and the project success dependent variable.

\section{Descriptive Statistics}

This study examined responses from 50 participants. Many participants held a project manager position $(39,78 \%)$ and were between the age of 30 to 40 years $(26,52 \%)$. Most participants held a bachelor's degree $(33,66 \%)$. A majority of participants had a certificate in construction management $(32,64 \%)$. Most participants were male $(39,78 \%)$. Many of the participants had 6 to 10 years of experience $(17,34 \%)$ in managing construction projects. Table 2 shows the frequencies and percentages of the participants' demographics.

Also, in this study, a review of the descriptive statistics of the five constructs in this study was completed (see Table 3). Means and standard deviations conducted on the five variables indicated that customer satisfaction scores had the largest mean $(M=4.34)$, followed by business success scores $(\mathrm{M}=4.31)$ with the lowest standard deviations of 0.56 and 0.52 respectively, as shown in Table 3 below. A low standard deviation indicates that the values tend to be close to the mean (also called the expected value) of the set.

Table 3: Descriptive Statistics of Constructs

\begin{tabular}{|l|c|c|}
\hline Variable & Mean & SD \\
\hline Risk Audits & 4.22 & 0.79 \\
\hline Schedule Performance & 4.20 & 0.66 \\
\hline Cost Performance & 4.11 & 0.60 \\
\hline Customer Satisfaction & 4.34 & 0.56 \\
\hline Business Success & 4.31 & 0.52 \\
\hline
\end{tabular}

\section{Inferential Statistics}

To answer the research questions in this study, SPSS version 26 software was used to perform the statistical analysis of the data collected; and a nonparametric Spearman's rho correlational analysis and simple logistic regressions were performed to test for significant associations between the independent and dependent variables. Statistical significance was assumed at an alpha value of .05, and the correlation analyses were interpreted and reported using a correlation matrix. Spearman's rho correlation interpretation is similar to that of Pearson's, e.g. the closer $r$ is to \pm 1 the stronger the monotonic relationship. Correlation is an effect size and the strength of association can be explained using the following terms and values: $.00-.19$ "very weak", .20-.39 "weak", .40-.59 "moderate", .60-.79 "strong", and .80-1.0 "very strong" (Laerd Statistics, 2018). These terms are used whether the value is + or - (Laerd Statistics, 2018; Schober, Boer, \& Schwarte, 2018). Also, correlation is expressed as a positive/negative relationship with the appropriate strength term applied (Schober, Boer, \& Schwarte, 2018).

To address research question 1, Spearman's rho correlational analysis was used to analyze data. The results from the analysis indicated a positive and significant association between risk audits and the four components of project success: schedule performance $(r h o=.66, p=.001)$, cost performance (rho $=.68, p=.001$ ), customer satisfaction ( $r h o=.76, p=.001)$, and business success $(r h o=.70, p=.001$; see Table 4$)$. 
K. C. Obondi The impact of project risk audit on construction project success

Table 2: Frequencies and Percentages of Demographics

\begin{tabular}{|c|c|c|}
\hline Variable & Level & Frequency $(\%)$ \\
\hline \multirow{5}{*}{ Age } & $18-29$ & $11(22)$ \\
\hline & $30-40$ & $26(52)$ \\
\hline & $41-50$ & $8(16)$ \\
\hline & $51-60$ & $4(8)$ \\
\hline & $61-65$ & $1(2)$ \\
\hline \multirow{2}{*}{ Gender } & Female & $11(22)$ \\
\hline & Male & $39(78)$ \\
\hline \multirow{5}{*}{$\begin{array}{l}\text { Years of } \\
\text { Experience }\end{array}$} & $3-5$ years & $11(22)$ \\
\hline & $6-10$ years & $17(34)$ \\
\hline & 11-15 years & $14(28)$ \\
\hline & 16-20 years & $7(14)$ \\
\hline & $21+$ years & $1(2)$ \\
\hline \multirow{5}{*}{ Education } & High school & $1(2)$ \\
\hline & Associate's degree & $1(2)$ \\
\hline & Bachelor's degree & $33(66)$ \\
\hline & Master's degree & $13(26)$ \\
\hline & Doctoral degree & $2(4)$ \\
\hline \multirow{5}{*}{ Job Title } & Project Manager & $39(78)$ \\
\hline & Project Coordinator & $2(4)$ \\
\hline & Project Analyst & $1(2)$ \\
\hline & Project Leader & $1(2)$ \\
\hline & Project Risk Manager & $7(14)$ \\
\hline \multirow{13}{*}{$\begin{array}{l}\text { Qualifications or } \\
\text { Certifications }\end{array}$} & Certificate in Construction Project Management & $32(64)$ \\
\hline & Capability Maturity Model Integration & $10(20)$ \\
\hline & Certificate in Project Management & $27(54)$ \\
\hline & Certificate in Risk Management & $24(48)$ \\
\hline & Certified Associate in Project Management & $13(26)$ \\
\hline & Information Technology Infrastructure Library & $14(28)$ \\
\hline & PMI Scheduling Professional & $3(6)$ \\
\hline & Program Management Professional & $7(14)$ \\
\hline & Project Management Professional & $15(30)$ \\
\hline & Projects in Controlled Environments (PRINCE2) & $5(10)$ \\
\hline & Six Sigma Black Belt & $6(12)$ \\
\hline & Six Sigma Green Belt & $4(8)$ \\
\hline & None of the above & $3(6)$ \\
\hline
\end{tabular}

Table 4: Correlations: Risk Audits and Project Success Outcomes (Schedule Performance, Cost Performance, Customer Satisfaction, and Business Success)

\begin{tabular}{|l|l|l|c|c|c|c|c|}
\hline & & $\begin{array}{c}\text { Risk } \\
\text { Audits }\end{array}$ & $\begin{array}{c}\text { Schedule } \\
\text { Performance }\end{array}$ & $\begin{array}{c}\text { Cost } \\
\text { Performance }\end{array}$ & $\begin{array}{c}\text { Customer } \\
\text { Satisfaction }\end{array}$ & $\begin{array}{c}\text { Business } \\
\text { Success }\end{array}$ \\
\hline $\begin{array}{l}\text { Spearman's } \\
\text { rho }\end{array}$ & $\begin{array}{l}\text { Risk } \\
\text { Audits }\end{array}$ & $\begin{array}{l}\text { Correlation } \\
\text { Coefficient }\end{array}$ & 1.000 & $.663^{* *}$ & $.678^{* *}$ & $.757^{* *}$ & $.704^{* *}$ \\
\hline & & Sig. (2-tailed) & & .000 & .000 & .000 & .000 \\
\hline & & $N$ & 50 & 50 & 50 & 50 & 50 \\
\hline
\end{tabular}

**Correlation is significant at the .01 level (2-tailed).

Based on the results from Table 4, the null hypothesis, which indicated no positive relationship between risk audits and project success in construction projects, was rejected. In this case, the alternative hypothesis (Ha1) was accepted. There was a positive relationship 
between the utilization of risk audits and project success in construction projects.

To address research question $\mathbf{2}$, simple logistic regressions analysis was used to analyze data to predict the magnitude of the relationship between risk audits and project success in construction projects. Simple logistic regressions test was performed with the impact of risk audits as the predictor variable on project success outcomes (schedule performance, cost performance, customer satisfaction, and business success) as successive dependent variables. Table 5 below shows the results of the coefficients, odds ratios, and associated probability values for each of the dependent variables.

In this study, the results from table 5 indicated that all project success outcomes (except for customer satisfaction and business success) were reliably predicted by the impact of risk audits. The values of the coefficients show that increased levels of agreement that utilization of risk audits is predictive of project success is significantly associated with an increase in odds by a factor of 20.11 times (95\% CI 2.41 and 167.55) in terms of schedule performance. Also, the values of the coefficients indicate that increased levels of agreement that utilization of risk audits is predictive of project success is significantly associated with an increase in odds by a factor of 4.98 times (95\% CI 1.17 and 21.28) in terms of cost performance. Both customer satisfaction and business success components of project success were not significantly predicted by the impact of risk audits.

Table 5: Project Success outcomes in Construction Projects by Risk Audits

\begin{tabular}{|c|c|c|c|c|c|c|}
\hline \multirow{2}{*}{ Outcomes } & \multicolumn{4}{|c|}{ Risk Audits } & \multirow{2}{*}{$\begin{array}{c}95 \% \mathrm{CI} \\
\text { for } \\
\operatorname{Exp}(\mathrm{B}) \\
\text { Lower }\end{array}$} & \multirow[b]{2}{*}{ Upper } \\
\hline & $\boldsymbol{B}$ & $S E$ & $\operatorname{Exp}(B)$ & $p$ & & \\
\hline Schedule Performance & 3.00 & 1.08 & 20.11 & $0.006^{* *}$ & 2.41 & 167.55 \\
\hline Cost Performance & 1.61 & 0.74 & 4.98 & $0.03 *$ & 1.17 & 21.28 \\
\hline Customer Satisfaction & 1.20 & 1.26 & 3.31 & 0.343 & 0.28 & 39.38 \\
\hline Business Success & 1.20 & 1.26 & 3.31 & 0.343 & 0.28 & 39.38 \\
\hline$* * p<.01, * p<.05$ & & & & & & \\
\hline
\end{tabular}

However, based on the results from table 5, the null hypothesis which indicated no predictive effect of risk audits on project success in construction projects was rejected. In this case, the alternative hypothesis (Ha2) was accepted. There was a predictive effect of risk audits on project success (in terms of schedule and cost performance) in construction projects.

\section{DISCUSSION}

This study examined the relationship between the utilization of risk audits and project success in construction projects. The specific problem addressed in this study was that construction companies are experiencing large financial deficits when project managers fail to implement risk audits in construction projects they oversee. The results of this study serve as a source of knowledge that practitioners can apply to manage and solve risks in their area of practice. The findings from this study will help organizations solve project risk management issues to ensure the delivery of successful projects.
The findings were evaluated based on the study's research questions and hypotheses. This study examined whether there was a relationship between the utilization of risk audits and project success in construction projects. Based on the Spearman's rho correlational analysis, the results showed a positive and significant association between risk audits and the four components of project success: schedule performance $(r h o=.66$, $p=.001)$, cost performance ( $r h o=.68, p=.001$ ), customer satisfaction ( $r h o=.76, p=.001)$, and business success ( $r h o=.70, p=.001$ ). These results showed that the relationship between the utilization of risk audits and project success was strong and positive in all of the four components of project success: schedule performance, cost performance, customer satisfaction, and business success (Laerd Statistics, 2018). In this case, there was a strong statistically significant positive relationship between the utilization of risk audits and project success. These results confirmed that the usage of risk audits led to a project being completed on schedule, within budget, and high 
customer satisfaction. Also, these results confirmed that the usage of risk audits led to the project being an economic business success in terms of return on investment.

Based on the simple logistic regression analysis, the results indicated that all project success outcomes (except for customer satisfaction and business success) were significantly predicted by the impact of risk audits. In other words, there was a predictive effect of risk audits on project success in terms of schedule and cost performance in construction projects. These results confirmed that the usage of risk audits led to a project being completed on schedule and within budget.

The implication of these findings suggested that the construction project manager's utilization of the risk audits technique positively affected the success rate of projects in the construction industry. In other words, this study found that risk auditing was useful in improving a construction project's schedule performance, cost performance, customer satisfaction with the end product, and business success in terms of return on investment. These findings align with previous studies on project risk audits, which have shown a positive relationship between project risk audits and project success. For example, in agreement with the finding of the current study, earlier studies by Eulerich and Kalinichenko (2018) and Lombardi, Vasarhelyi, and Verver (2014) found that the application of continuous risk auditing in construction projects improved a project's cash flow, accountability, and risk control. The authors also reported that audits increase the protection of project cash flow from being manipulated, improves fraud deterrence due to closer detection of fraud, strengthens vendor relations creating more effective procedures, stabilizes risk controls, and minimizes inherent risks, all leading to project success. Additionally, project risk audits help to improve the performance of the project, enhance customer and stakeholder satisfaction, save costs, control scope to avoid scope creep, provide early problem diagnostics, and clarify performance, cost, and schedule relationships. These findings are aligned with the current study's finding which indicated that there was a statistically significant positive relationship between the utilization of risk audits and project success in terms of schedule performance, cost performance, customer satisfaction, and business success in construction projects.

\section{Recommendations for Practice}

The findings from this study indicated that utilizing the risk audits technique can help determine a project's success. In other words, this suggests that the continuous utilization of risk audits technique by construction project managers enhances the success rate of a project in the construction industry in the United States. A recommendation that emerged from this study was that construction project managers should recognize the importance of the project risk audits technique and apply it to projects they oversee to solve risks for the successful delivery of their projects. This can be achieved through conducting periodic workshops, and training project managers to understand the importance of risk auditing practices. According to Tavakolan and Mohammadi (2018), a workshop allows the organization to identify critical risks. A workshop also helps an organization's staff have a better understanding of the project's environment and provides opportunities to improve teamwork. Also, in this case, training increases the project manager's awareness of the benefits of risk audits technique in project management. Additionally, Dubihlela and Gwaka (2020) asserted that the training and staffing of the internal audit function of a project help to diversify the skills of the auditing function and design effective riskmitigation measures to deal with the potential impact of emerging risks in a project. Omran (2016) found that training and human resources development are useful and significant for an organization to improve managers, employees, and organizational performance. The author argued that higher productivity comes with providing a good training program in a firm.

\section{Limitations and Future Research}

Limitations of the research are those factors that impact or influence the interpretations of the findings. The first shortcoming was possible that the research method could act as a limitation because the current methodology investigated statistical relationships between the variables. Since the participants were completing a designed survey, the data did not account for any expanded thoughts or experiences the participants may have had (Queirós, Faria, \& Almeida, 2017). However, to account for this limitation, the researcher ensured that the survey was administered in alignment with the study's problem, purpose, and research questions. The researcher administered 
the survey over the internet (Qualtrics website) via electronic mail, monitored responses as they were being returned, and sent reminders to nonrespondents. This alignment ensured that the collected data could answer the research questions.

The second limitation was the time restriction. Since the researcher utilized a survey where respondents visited the Qualtrics website, time could have been a limitation. For example, the survey might have seemed long (taking 15 to 20 minutes to complete), and some participants may not have completed the survey in its entirety due to time restraints. Any incomplete surveys could hinder the data collection process. To account for this limitation, the researcher ensured the survey was easy to complete and contained understandable questions. The researcher also utilized skip logics that prevented the participants from skipping any questions. All incomplete surveys were eliminated from the study. The third and final limitation was that this study was restricted to construction project managers working for construction companies in the DallasFort Worth area of Texas.

This study has several strengths that enhance the validity of the findings, and add to the need for future studies on this topic. Since this study was conducted in the United States, it is recommended that future research be conducted in developing countries to see whether the findings from the study are the same. Developing countries have different cultures that could change or impact the results. However, conducting the same study in developing countries could improve the objectivity and generalizability of the findings and provide insights and knowledge that could improve risk management in organizations (Lalayants, \& Tripodi, 2009).

Since this was a quantitative study, future studies could be conducted using mixed methods to explore this topic and see whether the findings remain the same. Using mixed methods to further explore this topic helps researchers to avoid biases intrinsic to a single-method approach, compare qualitative and quantitative data, and improve the accuracy of the study's findings to produce a complete picture of the phenomenon under study. McKim (2017) argued that studies that use a mixed-methods approach gain a deeper, broader understanding of the phenomenon than studies that do not utilize both a quantitative and qualitative approach. The integration component of mixed methods gives readers more confidence in the results and in the conclusions they draw from the study. Although mixed methods could be used in this study, using mixed methods can be expensive and time-consuming, especially when gathering qualitative and quantitative data simultaneously.

Finally, a true experimental design should be carried out on the same topic in this study to see whether there is a causal relationship (cause-effect relationship) between the independent and dependent variables. In other words, since this was a quantitative non-experimental correlational study, future studies could be conducted using a true experimental design to examine whether usage of risk audits technique causes a project's success. According to Podsakoff and Podsakoff (2019), experimental designs permit researchers to obtain consistent estimates of the effects of the independent variables on dependent variables. One reason for the use of experimental designs is their ability to provide evidence of causal relationships between variables. The power of experimental designs to establish cause-and-effect relationships creates knowledge and a better understanding of the phenomenon that is being studied.

\section{CONCLUSION}

The problem addressed in this study is that construction companies are experiencing large financial deficits because of a lack of constant risk auditing by construction project managers in construction projects they oversee. The purpose of this quantitative study was to examine whether the utilization of the risk audits technique is related to project success in construction projects. The findings of this study concluded that there was a statistically significant positive relationship between risk audits and project success. This study can be used as a source of knowledge that practitioners may utilize to manage and respond to risks in their area of practice. This study provides project management practitioners with a more profound and detailed understanding of the benefits and relationships that exist between project risk audits and project performance. The findings from this study can be used by organizations to formulate policies and procedures for solving project risk management issues to ensure the successful completion of their projects.

The utilization of the project risk audits technique is essential to the growth and sustainability of the construction industry. Frequent training on risk 
auditing practices is necessary to increase the awareness of risks and thereby potentially making the project more successful. By understanding the relationship between the utilization of the risk audits technique and project success, project managers will be better prepared to apply this technique to manage and solve risks in their area of practice.

The correlation between project success and the utilization of the risk audits technique seemed to be strong, positive, and significant as demonstrated in the results of this study. Although a correlational relationship did not prove causality, an increase in the usage of the risk audits technique increased project success. While research participants agreed that the usage of risk audits technique was a good idea, it seemed that risk audits technique was not widely used, causing construction organizations to experience significant financial deficits, sometimes up to $85 \%$ of the total cost of a project (Senesi, Javernick-Will, \& Molenaar, 2015). Although there are many risk management tools and techniques to be applied, many project managers are still either ignoring or reluctant to apply them to their projects. In this case, the lack of application of risk audits technique was due to the lack of awareness of the benefits of risk audits in the delivery of successful projects. Workshops and training can improve project managers' understanding of the relationship between the utilization of risk audits technique and project success.

Additionally, construction organizations should regularly consider the usage of risk audits techniques to improve the success rate of a project. Awareness, continuous application, and better training are needed to promote the understanding, usage, and usefulness of risk auditing function in construction projects. The results of this study indicated that the utilization of risk audits correlated with project success in construction projects. Therefore, as long as construction project managers are proactive and frequently apply risk auditing methods in their daily work, the utilization of the risk audits technique will continue to be part of a solution to many problems that exist in projects in the construction industry.

\section{REFERENCES}

Alashwal, A. M., \& Al-Sabahi, M. H. (2018). Risk factors in construction projects during unrest period in Yemen. Journalof Construction in Developing Countries, 23(2), 43-62. doi:10.21315/jcdc2018.23.2.4

Besteiro, E. C., Pinto, J. D., \& Novaski, O. (2015). Success factors in projectmanagement. Business Management Dynamics, 4(9), 19-34.

Chapman, R. J. (2019). Exploring the value of risk management for projects: Improving capability through the deployment of a maturity model. IEEE Engineering Management Review, 47(3), 126-143. doi:10.1109/EMR.2019.2891494

Coakes, S. J., \& Steed, L. (2009). SPSS: Analysis without anguish using SPSS version 14.0 for Windows. New York, NY: John Wiley \& Sons.

Curtis, E. A., Comiskey, C., \& Dempsey, O. (2016). Importance and use of correlational research. Nurse Researcher, 23(6), 20-25. doi:10.7748/nr.2016.e1382

D'souza, C. (2012). Examining the relationship between project risk management and information technology (IT) project success (Order No. 3572898). Available from ProQuest Dissertations \& Theses Global. (1433375409). Retrieved from https://proxy1.ncu.edu/login?url=https://searchproquest-

com.proxy1.ncu.edu/docview/1433375409?accounti $\mathrm{d}=28180$.

Dubihlela, J., \& Gwaka, L. T. (2020). Disruptive changes and emerging risks within internal auditing profession: A review from South Africa. Acta Universitatis Danubius. Economica, 16(3).

El-Sayegh, S. M. (2014). Project risk management practices in the UAE construction industry. International Journal of Project Organisation and Management, 6(1/2). doi:10.1504/IJPOM.2014.059748

Eulerich, M., \& Kalinichenko, A. (2018). The current state and future directions of continuous auditing research: An analysis of the existing literature. Journal of Information Systems, 32(3), 31-51. doi:10.2308/isys-51813

Hair, J. F., Money, A.H., Samouel, P., \& Page, M. (2007). Research methods for business. Chichester, England: John Wiley \& Sons.

Hardy, C. A., \& Laslett, G. (2015). Continuous auditing and monitoring in practice: Lessons from Metcash's business assurance group. Journal of Information Systems, 29(2), 183-194. doi:10.2308/isys-50969.

Hoffmann, J. P., \& Shafer, K. (2015). Linear regression analysis. Washington, DC: NASW Press.

Jayasudha, K., Vidivelli, B., \& Surjith, E.R.G. (2014). Risk assessment and management in construction projects. International Journal of Scientific \& Engineering Research. 5(8), 387-96.

Khan, R. A., \& Gul, W. (2017). Empirical study of critical risk factors causing delays in construction 
projects. Presented at the 9th IEEE International Conference on Intelligent Data Acquisition and Advanced Computing Systems: Technology and Applications (IDAACS, 21-23 September 2017), Bucharest, Romania. doi:10.1109/IDAACS.2017.8095217

Kline, R. B. (2005). Principles and practice of structural equation modeling. New York, NY: Guilford Press.

Laerd Statistics (2018). Spearman's correlation using SPSS statistics. Statistical tutorials and software guides. Retrieved from https://statistics.laerd.com/

Lalayants, M., \& Tripodi, T. (2009). A review of generalization methods used in empirical social work literature. International Journal of Social Welfare, 18(4), 333. doi:10.1111/j.14682397.2008.00634.x

Leedy, P. D., \& Ormrod, J. E. (2013). Practical research: Planning and design. Saddle River, NJ: Merrill.

Lombardi, D. R., Vasarhelyi, M. A., \& Verver, J. (2014). Continuous controls monitoring: A case study. Journal of Emerging Technologies in Accounting, 11(1), 83-98. doi:10.2308/jeta-51006

Lu, D. (2004). U.S. Patent Application No. 10/640,213.

McCusker, K., \& Gunaydin, S. (2015). Research using qualitative, quantitative, or mixed methods and choices based on the research. Perfusion, 30(7), 537542. doi:10.1177/0267659114559116

McKim, C. A. (2017). The value of mixed methods research: A mixed methods study. Journal of Mixed Methods Research, 11(2), 202-222. doi: $10.1177 / 1558689815607096$

Omran, A. (2016). Examining the effect of training strategies on employees' performance in the Libyan construction industry. Journal of Engineering Management and Competitiveness (JEMC), 6(2), 99110.

Ott, R. L., \& Longnecker, M. T. (2015). An introduction to statistical methods and data analysis. Toronto, Canada: Nelson Education.

Park, J., \& Park, M. (2016). Qualitative versus quantitative research methods: Discovery or justification? Journal of Marketing Thought, 3(1), 17. doi:10.15577/jmt.2016.03.01.1

Podsakoff, P. M., \& Podsakoff, N. P. (2019). Experimental designs in management and leadership research: Strengths, limitations, and recommendations for improving publishability. The Leadership Quarterly, 30(1), 11-33. doi:10.1016/j.leaqua.2018.11.002

Polit, D. F., \& Beck, C. T. (2010). Generalization in quantitative and qualitative research: Myths and strategies. International Journal of Nursing Studies, 47(11), 1451-1458. doi:10.1016/j.ijnurstu.2010.06.004

ProjectManagement Institute. (2017). A guide to the project management body of knowledge (PMBOK ${ }^{\circledR}$ Guide) $\left(6^{\text {th }}\right.$ ed.). Newtown Square, PA: Project Management Institute.
Qazi, A., Quigley, J., Dickson, A., \& Kirytopoulos, K. (2016). Project complexity and risk management (ProCRiM): Towards modeling project complexity driven risk paths in construction projects. International Journal of Project Management, 34(7), 1183-1198. doi:10.1016/j.ijproman.2016.05.008

Queirós, A., Faria, D., \& Almeida, F. (2017). Strengths and limitations of qualitative and quantitative research methods. European Journal of Education Studies, 3(9), 369-386. doi:10.46827/ejes.v0i0.1017

Ryor, M. M. (2013). Utilization of risk management practices by construction project managers in the United States (Order No. 3567627). Available from ProQuest Dissertations \& Theses Global. (1424273936). Retrieved from https://proxy1.ncu.edu/login?url=https://searchproquestcom.proxy1.ncu.edu/docview/1424273936?accounti $\mathrm{d}=28180$.

Schober, P., Boer, C., \& Schwarte, L.A. (2018). Correlation coefficients: Appropriate use and interpretation. Anesthesia \& Analgesia, (126)5, 1763-1768. doi:10.1213/ANE.0000000000002864

Senesi, C., Javernick-Will, A., \& Molenaar, K. R. (2015). Benefits and barriers to applying probabilistic risk analysis on engineering and construction projects. Engineering Management Journal, 27(2), 49-57. doi:10.1080/10429247.2015.1035965

Shenhar, A. J., \& Dvir, D. (2007). Reinventing project management: The diamond approach to successful growth and innovation. Boston, MA: Harvard Business School Press.

Shenhar, A. J., Levy, O., \& Dvir, D. (1997). Mapping the dimensions of project success. Project management journal, 28(2), 5-13.

Shilts, J. (2017). A framework for continuous auditing: Why companies don't need to spend big money. Journal of Accountancy, 223(3), 1-7.

Sohu, S., Jhatial, A. A., Ullah, K., Lakhiar, M. T., \& Shahzaib, J. (2018). Determining the critical success factors for highway construction projects in Pakistan. Engineering, Technology \& Applied Science Research, 8(2), 2685-2688. doi: 10.48084/etasr.1866

Tavakolan, M., \& Mohammadi, A. (2018). Risk management workshop application: a case study of Ahwaz Urban Railway project. International Journal of Construction Management, 18(3), 260274. doi:10.1080/15623599.2017.1325112

Thaheem, M. J., \& De Marco, A. (2013, January). A survey on usage and diffusion of project risk management techniques and software tools in the construction industry. In Proceedings of World Academy of Science, Engineering and Technology (No. 78, p. 1096). World Academy of Science, Engineering and Technology (WASET). 
Todorovic, M. L., Petrovic, D. C., Mihic, M. M., Obradovic, V. L., \& Bushuyev, S. D. (2015). Project success analysis framework: A knowledge-based approach in project management. International Journal of Project Management, 33(4), 772-783. doi: 10.1016/j.ijproman.2014.10.009
Williams, T. (2016). Identifying success factors in construction projects: A case study. Project Management Journal, 47(1), 97-112. doi: $10.1002 / \mathrm{pmj} .21558$

\section{UTICAJ REVIZIJE RIZIKA U PROJEKTU NA USPEH GRAĐEVINSKOG PROJEKTA}

Revizija rizika se često loše primenjuje u građevinskim projektima zbog odsustva stalne revizije rizika od strane rukovodilaca građevinskih projekata. Građevinske kompanije imaju velike finansijske gubitke zbog toga što rukovodioci ne uspevaju da izvrše reviziju i nadgledanje projektnih rizika. Cilj ovog rada je bilo ispitivanje da li postoji korelacija između primene revizije rizika i uspeha građevinskih projekata. Elektronski upitnik je korišćen za prikupljanje podataka . Uzorak obuhvata 50 rukovodilaca građevinskih projekata u Dallas-Fort Vorth oblasti u Teksasu u Sjedinjenim Američkim Državama. Za ispitivanje odnosa između revizije rizika i uspeha projekata korišćena je Spearman-ova rho korelacijska analiza i jednostavna logistička regresija. Rezultati ukazuju na to da postoji pozitivna $i$ značajna veza između revizija rizika i uspeha projekata sa aspekta performansi rasporeda , troškova, zadovoljstva kupaca i poslovnog uspeha . Jedna od preporuka u ovom radu je bila proširenje istraživanja na zemlje u razvoju kako bi se utvrdilo da li će rezultati tih istraživanja ostati isti. Zaključeno je da građevinske kompanije treba redovno da razmatraju značaj i upotrebu tehnike revizije rizika kako bi poboljšale stopu uspešnosti projekta.

Keywords: Upravljanje građevinskim projektima; Uspeh projekta; Revizija; Revizije projektnog rizika; Revizija projekta. 